\title{
IMPACT OF FIRM SPECIFIC FACTORS ON PROFITABILITY OF INDUSTRIAL GRINDING COMPANIES
}

\author{
Snežana Milošević Avdalović ${ }^{1}$ \\ *Corresponding author E-mail: smilosevic@ef.uns.ac.rs
}

\begin{abstract}
A R T I C LE IN F O
A B S T R A C T

Original Article

Received: 03 October 2017

Accepted: 15 March 2018

doi:10.5937/ekoPolj1802493M

UDC 005.346:347.779

Keywords:

industrial grinding companies, firm specific factors, return on equity

JEL: Q12, L66, C32

In this paper, panel ordinary least squares model of industrial grinding companies listed on Belgrade Stock Exchange was used for examining the determinants of profitability. For this purpose, 62 observations of companies over the period of 2008 - 2014 were included. Return on equity considered as a measure for profitability is a dependent variable whereas size, leverage, years of firm existence, number of stock and book value per share are considered as independent variables. According to the findings, leverage, number of stock and book value per share are statistically significant of inverse relationship with profitability for selected listed industrial grinding companies in Serbia. Size $(+)$ and age (-) indicate insignificant impacts on profitability. The results revealed that all independent variables explain $84.4 \%$ of the variance on return on equity. The results of Granger causality test indicated causality between profitability and leverage, profitability and number of stocks are bidirectional.
\end{abstract}

(C) 2018 EA. All rights reserved.

\section{Introduction}

Firms' profitability and ways of improving it are hotly debated issues among managers and scholars. Identification of the sources of variation in firm level profitability is an important research theme in economics, strategic management and accounting and finance (Goddard, Tavakoli \& Wilson, 2005). It is known that the determinants of the profitability of manufacturing firms are very important in accordance with the economic development of any country, therefore, more research in this area is necessary. Stekla and Grycova (2016) said that the capital structure decision is very important because a bad decision can affect a company's profitability leading to a decrease in the shareholders' value. Several empirical studies have attempted to identify firm profitability determinants, focusing on firms in different industry sectors and in different periods (e.g. McDonald, 1999; Adams and Buckle, 2003; Yazdanfar, 2013; Tomsik et al., 2016; Kroupova, 2016). Profitability of the firm is highly influenced by internal and external variables.

1 Snežana Milošević Avdalović, Teaching Assistant, University of Novi Sad, Faculty of Economics Subotica, Segedinski put no. 9-11, 24000 Subotica, Republic of Serbia, +38124628059, e-mail: smilosevic@ef.uns.ac.rs, http://www.ef.uns.ac.rs 
The study therefore proposed the following research questions:

1. What is the relationship between Firm size and corporate profitability?

2. What is the relationship between Years of firm existence and corporate profitability?

3. What is the relationship between Financial Leverage and corporate profitability?

4. What is the relationship between Number of stock and corporate profitability?

5. What is the relationship between Book value per share and corporate profitability?

Objectives of the Study

The objectives of the study are to:

1. Analyze the relationship between Firm size and corporate profitability?

2. Analyze the relationship between Years of firm existence and corporate profitability?

3. Analyze the relationship between Financial Leverage and corporate profitability?

4. Analyze the relationship between Number of stock and corporate profitability?

5. Analyze the relationship between Book value per share and corporate profitability?

The Tested Hypotheses

This study tests the following five null hypotheses: The following hypotheses have been developed to achieve the stated objectives

H01: There is statistical significant relationship between firm's size and profitability of industrial grinding companies in Serbia

H02: There is statistical significant relationship between years of firm existence and profitability of industrial grinding companies in Serbia

H03: There is statistical significant relationship between financial leverage and profitability of industrial grinding companies in Serbia

H04: There is statistical significant relationship between quotation on the stock exchange (number of stocks) and profitability of industrial grinding companies in Serbia

H05: There is statistical significant relationship between book value per share and profitability of industrial grinding companies in Serbia

Current studies do indicate that panel data analysis is more suitable than other methods of study in determining the profitability of manufacturing companies. Therefore, this research paper also hopes to explore the relative importance of determinant of profitability of industrial grinding companies in Serbia by using the panel data analysis.

Pratheepan (2014) concluded that size is statistically significant of positive relationship with profitability (Return on assets) whereas tangibility showed statistically significant of inverse relationship with profitability for selected listed manufacturing companies in Sri Lanka. Leverage and liquidity indicated insignificant impacts on profitability. 
Sivathaasan et al. (2013) investigated whether factors such as capital structure, working capital, firm size, non-debt tax shield and growth rate, determining profitability have any impact on profitability of selected manufacturing companies listed on Colombo stock exchange, Sri Lanka over a period of five years from 2008 to 2012. The results revealed that whereas all independent variables explain $76.6 \%$ and $84.7 \%$ of the variance on ROA and ROE respectively where significant is at 5\% levels. Further, while capital structure $(+)$ and non-debt tax shield $(+)$ have statistically significant impact on profitability, the remaining working capital $(+)$, growth rate $(-)$ and firm size $(+)$ have no significant effect on the profitability.

Azhagaiah and Deepa (2012) showed that volatility and growth are the major predictors in determining profitability in case of small size firms while growth is important in determining the profitability of medium size firms. Capital intensity has a significant positive coefficient with the profitability of large size firms. The overall result showed that the larger the size of the firm, the more the investment in long lived assets has helped to increase the profitability of the firm unlike the trend in cases of small size and medium size firms.

Vătavu (2014) established the determinants of financial performance in 126 Romanian companies listed on the Bucharest Stock Exchange, over a period of ten-years (20032012). Regression results indicated that profitable companies operate with limited borrowings. Tangibility, business risk and the level of taxation have a negative impact on return on assets. Although earnings are sustained by significant sales turnover, performance is affected by high levels of liquidity. Periods of unstable economic conditions, reflected by high inflation rates and the current financial crisis, have a strong negative impact on corporate performance.

Bhayani (2010) covered the all listed cement firms working in India for the period of 2001 to 2008. To determinant profitability backward regression analysis were used on the variables of the study. The result of the study showed that liquidity, age of the firm, operating profit ratio, interest rate and inflation rate has played a vital role in the determination of the profitability of Indian Cement Industry.

Al-Jafari and Al Samman (2015) investigated the determinants of profitability for industrial firms in Oman. Therefore, a sample of 17 industrial companies listed on Muscat securities market covering the period from 2006 till 2013 is utilized. Results from the panel ordinary least squares model revealed a positive and statistical significant relationship between profitability, the firm size, growth, fixed assets and working capital. On the other hand, the average tax rate and the financial leverage variables showed a negative relationship with profitability. However, this relationship was significant only for the financial leverage variable. The study concluded that large growing firms with efficiently managed assets improve revenue and ultimately enhance profitability.

Stekla and Grycova (2016) found a negative relationship between the profitability and debt across of agricultural holdings in the Czech Republic for a period of six years from 2008 to 2013. 


\section{Materials and methods}

In summary, studies researching the determinants of profitability have identified several factors. The impact of specific firm factors was derived from previous studies - theoretical and empirical concepts. To analyze the factors which influence the profitability of industrial grinding companies in Serbia.

Table 1. Research variables - dependent and independent variables

\begin{tabular}{|l|l|l|c|}
\hline Symbol & \multicolumn{1}{|c|}{ Measurement } & $\begin{array}{c}\text { Expected } \\
\text { sign }\end{array}$ \\
\hline \multicolumn{2}{|c|}{ Independent variable } & \\
\hline ROE & Profitability & Return on equity & \\
\hline \multicolumn{2}{|c|}{ Dependent variables } & \\
\hline SIZE & Firms' size & Total Assets & + \\
\hline AGE & Years of firm existence & Number of years of firm existence & $+/-$ \\
\hline LEV & Leverage ratio & Ratio between total loans and equity & - \\
\hline STOCK & Quotation on the stock exchange & Number of stocks & - \\
\hline BV & Capital structure & Book value per stock & - \\
\hline
\end{tabular}

Source: Author

In order to obtain a regression model, it was necessary to determine: which observed factors influence the profitability of industrial grinding companies, by what intensity and in what direction.

The panel ordinary least squares model is used as in equation 1 to examine the effect of the independent variables on the dependent variable of profitability of industrial grinding companies in Serbia, and to test the above five null hypotheses:

$R O E=\beta 0+\beta_{1} S I Z E_{i t}+\beta 2 A G E_{i t}+\beta 3 L E V_{i t}+\beta 4 S T O C K_{i t}+\beta 5 B V_{i t}+\varepsilon_{i t}$

Where:

Profitability: Measured by return on equity (ROE)

$\beta 0=$ Coefficient of Intercept (Constant)

$\beta 1-\beta 5=$ Coefficients of Slope

$\mathrm{e}=$ error term.

$\mathrm{i}, \mathrm{t}$ - company (i) in time (t) 


\section{Results and Discussions}

Descriptive statistics for the variables are given in Table 2. The descriptive statistics is based on 9 industrial grinding companies' 7 years data set which includes 62 observations.

Table 2. Descriptive statistics of variables

\begin{tabular}{|c|c|c|c|c|c|c|}
\hline & ROE & SIZE & AGE & LEV & STOCK & BV \\
\hline Mean & -0.123440 & 1183790. & 16.32258 & 2.074137 & 246129.9 & 11318.53 \\
\hline Median & 0.036715 & 882077.0 & 16.50000 & 0.928787 & 124433.0 & 1876.152 \\
\hline Maximum & 0.580337 & 3289873. & 24.00000 & 42.21247 & 1465771. & 51398.05 \\
\hline Minimum & -4.323703 & 91202.00 & 9.000000 & 0.046635 & 32757.00 & 24.23442 \\
\hline Skewness & -4.722447 & 0.729367 & 0.008034 & 6.482181 & 2.594759 & 1.487105 \\
\hline Kurtosis & 26.34651 & 2.183138 & 1.785200 & 46.86051 & 8.006591 & 3.615555 \\
\hline Jarque-Bera & 1638.519 & 7.220850 & 3.812991 & 5403.866 & 134.3257 & 23.83083 \\
\hline Probability & 0.000000 & 0.027040 & 0.148600 & 0.000000 & 0.000000 & 0.000007 \\
\hline Observations & 62 & 62 & 62 & 62 & 62 & 62 \\
\hline
\end{tabular}

Source: Author

Table 2 comprises the main descriptive statistics for the variables used in the analysis. Furthermore, the table above indicates that there is high variation in return on equity. This result is consistent with high variation in financial leverage variable because higher degree of financial leverage will lead to more volatility in earnings. The correlation matrix for the variables is reported in Table (3).

Table 3. Correlation between variables

\begin{tabular}{|l|l|l|l|l|l|l|}
\hline & \multicolumn{1}{|c|}{ ROE } & \multicolumn{1}{c|}{ SIZE } & \multicolumn{1}{c|}{ STOCK } & \multicolumn{1}{|c|}{ LEV } & AGE & BV \\
\hline ROE & 1 & & & & & \\
\hline SIZE & -.153 & 1 & & & & \\
\hline STOCK &.$- .517^{* *}$ & $-.363^{* *}$ & 1 & & & \\
\hline LEV & $-.905^{* *}$ & .156 & $.467^{* *}$ & 1 & & \\
\hline AGE & .078 & -.125 & -.124 & -.058 & 1 & \\
\hline BV & .107 & $.693^{* *}$ & $-.698^{* *}$ & -.151 & -.135 & 1 \\
\hline
\end{tabular}

Source: Author

Note: **Correlation is significant at the 0.01 level (2-tailed).

Table 3 shows that there are negative and significant relationship between return on equity and leverage and number of stock. In addition, we can observe that there is no significant relationship between return on equity and size, age and book value.

One of the requirements for testing a good multi-regression model is the non-linearity of the model between independent variables. It is imperative to check for multi-collinearity between the independent variables before we utilize the regression techniques. In general, there are the tolerance test and the variance inflation factor test (VIF) that can detect multi-collinearity. The tolerance level test represents the reciprocal value of the VIF test and is interpreted as a percentage of the variance of the predictor that is independent of the other predictors. The arbitrary value for the multi-collinearity indicator represents for a VIF amount greater than 10, i.e. tolerance level is less than 0.1. The variance inflation factor (VIF) for the test of multi-collinearity measures the relationship of all predictor variables concurrently. It explains how much the variance of a coefficient is inflated due to linear dependence with other explanatory variables. 
Table 4. Multi-collinearity statistics - Tolerance test and variance inflation factor

\begin{tabular}{|l|c|c|}
\hline \multicolumn{1}{|c|}{ Independent variable } & Tolerance (1/VIF) & VIF (>10 collinearity problem) \\
\hline SIZE & .449 & 2.228 \\
\hline STOCK & .341 & 2.936 \\
\hline AGE & .880 & 1.136 \\
\hline LEV & .655 & 1.528 \\
\hline BV & .270 & 3.705 \\
\hline \multicolumn{2}{|c|}{ Mean VIF: $\mathbf{2 . 3 0 6 6}$} \\
\hline
\end{tabular}

Source: Author

Values of tolerance test and variance inflation factor in the VIF test are significantly below the critical values and it can be concluded that the assumption of non-existence of multi-collinearity for model was not impaired. The mean value of VIF (Table 4) is 2.3066, less than 10, which confirms the absence of any multi-collinearity, and the VIF test for individual variables does not exceed the maximum value of 10, and therefore there is no need to eliminate certain variables from the regression analysis. It can be concluded that there is no multi-collinearity problem in this regression model. Further diagnostic tests are executed to ascertain the validity of the model.

Table 5. Heteroskedasticity Test: ARCH

\begin{tabular}{|l|l|l|l|}
\hline F-statistic & 0.465125 & Prob. F(1,59) & 0.4979 \\
\hline Obs*R-squared & 0.477130 & Prob. Chi-Square(1) & 0.4897 \\
\hline
\end{tabular}

Source: Author

The test for heteroskedasticity $(\mathrm{ARCH})$ also reveals an F-statistic and Obs*Rsquared probability values of 0.4979 and 0.4897 respectively, both of which are greater than 0.05 , and indicates the absence of heteroskedasticity.

Table 6. Breusch-Godfrey Serial Correlation LM Test

\begin{tabular}{|l|l|l|l|}
\hline F-statistic & 1.408213 & Prob. F(2,54) & 0.2534 \\
\hline Obs*R-squared & 3.073380 & Prob. Chi-Square(2) & 0.2151 \\
\hline
\end{tabular}

Source: Author

Breusch-Godfrey serial correlation test, used to investigate the presence or absence of autocorrelation. The F-statistic and $\mathrm{Obs}^{*} \mathrm{R}$-squared probability values are greater than 0.05 ( $5 \%$ level of confidence), which indicates the absence of autocorrelation in the model. 
Table 7. Impact of Firm Specific Factors on profitability of industrial grinding companies

\begin{tabular}{|c|c|c|c|c|c|c|c|}
\hline & \multirow[t]{2}{*}{ Model } & \multicolumn{2}{|c|}{$\begin{array}{l}\text { Unstandardized } \\
\text { Coefficients }\end{array}$} & $\begin{array}{l}\text { Standardized } \\
\text { Coefficients }\end{array}$ & \multirow[t]{2}{*}{ t } & \multirow[t]{2}{*}{ Sig. } & \multirow{2}{*}{$\begin{array}{l}\text { Model } \\
\text { Quality }\end{array}$} \\
\hline & & $\mathrm{B}$ & Std. Error & Beta & & & \\
\hline \multirow{8}{*}{1} & (Constant) & 2.543 & .977 & & 2.601 & .012 & \multirow{8}{*}{$\begin{array}{l}\text { Adjusted R } \\
\text { Square } \\
0.844 \\
\text { F (Sig.) } \\
67.058(.000) \\
\text { Durbin-Watson } \\
\text { stat } \\
2.094315\end{array}$} \\
\hline & SIZE & .026 & .050 & .039 & .515 & .608 & \\
\hline & \multirow{2}{*}{ Model } & \multicolumn{2}{|c|}{$\begin{array}{l}\text { Unstandardized } \\
\text { Coefficients }\end{array}$} & $\begin{array}{c}\text { Standardized } \\
\text { Coefficients }\end{array}$ & \multirow{2}{*}{$\mathbf{t}$} & \multirow{2}{*}{ Sig. } & \\
\hline & & B & Std. Error & Beta & & & \\
\hline & STOCK & -.220 & .059 & -.323 & -3.731 & .000 & \\
\hline & AGE & -.006 & .008 & -.040 & -.748 & .458 & \\
\hline & LEV & -.102 & .008 & -.804 & -12.868 & .000 & \\
\hline & BV & .000 & .000 & -.273 & -2.800 & .007 & \\
\hline
\end{tabular}

Source: Author

The results of the regression model and their statistically significant coefficients presented in table above. Leverage, number of stocks and book value per share are the determinants of return on equity. The presented coefficients in the table above indicate the direction of the relationship between independent variables and the dependent variable. By comparing the absolute values, leverage (-), number of stocks (-) and book value per share (-) have statistically significant influence respectively according to their intensity. An analysis of the model obtained for profitability of industrial grinding companies indicates negative impact of leverage, number of stock and book value per share, that is, with the increase of negatively correlated independent variables, there is a decrease in the value of return on equity. The validity tests of the model, i.e. the $F$, Durbin-Watson, ANOVA and VIF, confirm that the results are robust. In addition, the adjusted R2 (84.4\%) is high, indicating that the explanatory variables have a significant ability to explain change in the dependent variable.

Based on above results the researcher accepts or rejects the following hypothesis.

$\mathrm{H}_{01}$ : There is statistical significant relationship between firm's size and profitability of industrial grinding companies in Serbia. Rejected

$\mathrm{H}_{02}$ : There is statistical significant relationship between years of firm existence and profitability of industrial grinding companies in Serbia. Rejected

$\mathrm{H}_{03}$ : There is statistical significant relationship between financial leverage and profitability of industrial grinding companies in Serbia. Accepted

$\mathrm{H}_{04}$ : There is statistical significant relationship between quotation on the stock exchange (number of stocks) and profitability of industrial grinding companies in Serbia. Accepted 
$\mathrm{H}_{05}$ : There is statistical significant relationship between book value per share and profitability of industrial grinding companies in Serbia. Accepted

Table 8. Pairwise Granger Causality Tests

\begin{tabular}{|l|c|c|r|}
\hline Null Hypothesis: & Obs & F-Statistic & Prob. \\
\hline SIZE does not Granger Cause ROE & 60 & 1.28154 & 0.2858 \\
\hline ROE does not Granger Cause SIZE & & 0.16225 & 0.8506 \\
\hline BV does not Granger Cause ROE & 60 & 0.11348 & 0.8929 \\
\hline ROE does not Granger Cause BV & & 0.19596 & 0.8226 \\
\hline LEV does not Granger Cause ROE & $\mathbf{6 0}$ & $\mathbf{3 . 6 8 0 6 0}$ & $\mathbf{0 . 0 3 1 6}$ \\
\hline ROE does not Granger Cause LEV & & 3.56644 & $\mathbf{0 . 0 3 5 0}$ \\
\hline STOCK does not Granger Cause ROE & $\mathbf{6 0}$ & $\mathbf{1 1 . 5 9 8 5}$ & $\mathbf{6 . E - 0 5}$ \\
\hline ROE does not Granger Cause STOCK & 60 & 3.43954 & $\mathbf{0 . 0 3 9 1}$ \\
\hline AGE does not Granger Cause ROE & & 0.71415 & 0.4941 \\
\hline ROE does not Granger Cause AGE & 0.02923 & 0.9712 \\
\hline
\end{tabular}

Source: Author

The results of Granger Causality Test for the sample indices during the study period is presented in Table 8 . We have found that causality between profitability (ROE) and leverage (LEV), profitability and number of stocks (STOCK) are bidirectional, no causality exist between profitability (ROE) and size (SIZE), return on equity (ROE) and age, and return on equity (ROE) and book value per share (BV). The results indicate that, there is bidirectional causality that return on equity have a feedback effect on leverage and number of stocks.

\section{Conclusions}

The general of objective of this study was to evaluate the determinants of the profitability of industrial grinding companies in Serbia. A panel ordinary least squares technique is utilized on a sample of 9 industrial grinding companies covering the period 2008 till 2014. The results show a significant negative relationship between leverage, number of stocks, book value per share and profitability. Size $(+)$ and age (-) variables found to have insignificant relationship with profitability. The findings of this study are similar to the results of some variables utilized by Nunes et al. (2009), Asimakopoulos et al. (2009), Sivathaasan et al. (2013), Al-Jafari and Al Samman. (2015). It is known that the determinants of the profitability of manufacturing firms are very important in accordance with the economic development of any country, therefore, more research in this area is necessary.

\section{Conflict of interests}

The authors declare no conflict of interest. 


\section{References}

1. Adams, M., \& Buckle, M. (2003). The determinants of corporate financial performance in the Bermuda insurance market. Applied Financial Economics, 13(2), 133-143. doi: 10.1080/09603100210105030

2. Al-Jafari1, M.K., \& Al Samman, H. (2015). Determinants of Profitability: Evidence from Industrial Companies Listed on Muscat Securities Market. Review of European Studies, 7(11), 303-311. doi:10.5539/res.v7n11p303

3. Asimakopoulos, I., Samitas, A., \& Papadogonas, T. (2009). Firm-specific and economy wide determinants of firm profitability: Greek evidence using panel data. Managerial Finance, 35(11), 930-939.

4. Azhagaiah, R., \& Deepa, R. (2012). Determinants of Profitability of Food Industry in India: A Size-Wise Analysis. Management, 7(2), 111-128.

5. Bhayani, S. J. (2010). Determinants of profitability in Indian cement industry: An economic analysis. South Asian Journal of Management, 17(4), 6-20.

6. Goddard, J., Tavakoli, M., \& Wilson, J. O. (2005). Determinants of profitability in Europeanmanufacturingand services: evidence fromadynamic panelmodel.Applied Financial Economics, 15(18), 1269-1282. doi: 10.1080/09603100500387139

7. Kroupova, Z. Z. (2016). Profitability development of Czech dairy farms. Agricultural Economics (Zemédělská ekonomika), 62(6), 269-279.

8. McDonald, J. T. (1999). The determinants of firm profitability in Australian manufacturing. Economic Record, 75(2), 115-126.

9. Nunes, P. J. M., Serrasqueiro, Z. M., \& Sequeira, T. N. (2009). Profitability in Portuguese service industries: a panel data approach. The Service Industries Journal, 29(5), 693-707. doi: 10.1080/02642060902720188

10. Pratheepan, T. (2014). A panel data analysis of profitability determinants empirical results from Sri Lankan manufacturing companies. International Journal of Economics, Commerce and Management, 12(2) 1-9.

11. Sivathaasan, N., Tharanika, R., Sinthuja, M., \& Hanitha, V. (2013). Factors determining profitability: A study of selected manufacturing companies listed on Colombo Stock Exchange in Sri Lanka. European Journal of Business and management, 5(27), $99-107$.

12. Stekla, J., \& Grycova, M. (2016). The relationship between profitability and capital structure of the agricultural holdings in the Czech Republic. Agricultural Economics (Zemědělská ekonomika), 62(9), 421-428.

13. Tomsik, P., Stojanova, H., Sedlo, J., \& Vajcnerova, I. (2016). Factors of profitability of the grapes production. Agricultural Economics (Zemédělská ekonomika), 62(6), 292-297.

14. Vătavu, S. (2014). The determinants of profitability in companies listed on the Bucharest stock exchange. Annals of the University of Petrosani, Economics, 14(1), 329-338.

15. Yazdanfar, D. (2013). Profitability determinants among micro firms: evidence from Swedish data. International Journal of Managerial Finance, 9(2), 151-160. 